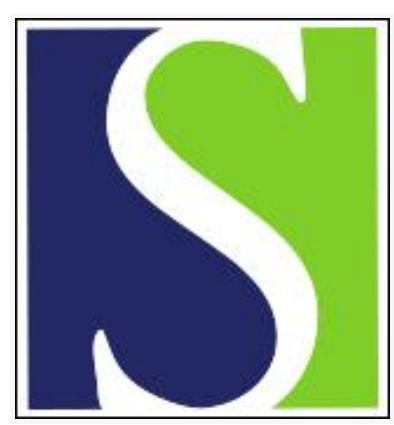

Scand J Work Environ Health 1987;13(1):1-8

https://doi.org/10.5271/sjweh.2086

Issue date: Feb 1987

Psychological stress experienced by health care personnel. by Leppanen RA, Olkinuora MA

This article in PubMed: www.ncbi.nlm.nih.gov/pubmed/3554496

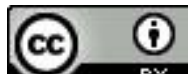




\title{
Psychological stress experienced by health care personnel
}

\author{
by R Anneli Leppänen, $\mathrm{PhL}^{1}$, Martti A Olkinuora, $\mathrm{MD}^{1}$
}

\begin{abstract}
LEPPÄNEN RA, OLKINUORA MA. Psychological stress experienced by health care personnel Scand $J$ Work Environ Health 13 (1987) $1-8$. Health care personnel consider the challenge of their work to be the principal reason for job satisfaction. Problems of work organization and the small number of personnel cause quantitative overload that has been perceived as problematic by various professional groups in health care units. Role ambiguity and role conflicts are also experienced frequently. Social contacts between patients and personnel, as well as social contacts among the personnel themselves, are sometimes thought to be very problematic. The increase in violent behavior towards health care personnel is a central stressor of their work. The way that work characteristics and strain are experienced, however, is affected by the profession and, especially, by the workplace. Psychological stress reactions are relatively common among health care personnel. The effects of work reorganization, the clarification of responsibilities, increased supplementary training and professional supervision, and the application of directions for the prevention of violence on the stress and strain of health care professionals should be studied as a means to diminish stress and increase well-being and productivity.
\end{abstract}

Key terms: role ambiguity, role conflicts, stress prevention, stress reactions, work challenge.

Some work characteristics affect man's well-being through psychological functions. These characteristics are usually called the psychological stressors of work if they cause strain. Psychological stress at work can be related to the contents and organization of work, responsibility at work, work roles, social contacts at work, and the terms of employment.

Discrepancy between the demands of a person's surroundings and his individual characteristics may result in stress. Efforts to correct for the discrepancy are made by the psychophysiological mechanism which maintains homeostasis. Stress is manifested through physiological functions, performance, behavior, and subjective symptoms. Stress-related changes are considered to be nonspecific $(18,27)$.

Studies on occupational stress often use subjective symptoms to measure stress reactions. Psychological and psychosomatic symptoms have been shown to be related to stress in various professional groups (12). Recent studies have also revealed that workers in professions involving intense social contacts experience symptoms related to the loss of mental resources (known as the burnout phenomenon) (24). Research on the stress of health care personnel has mainly considered subjective symptoms. Psychophysiological measurements or changes in work performance have not been used to assess the level of stress.

Several studies on mental load and stress among health care personnel have been published recently, but most of them have dealt only with the problems of one

\footnotetext{
Institute of Occupational Health, Helsinki, Finland.
}

Reprint requests to: Ms RA Leppänen, Institute of Occupational Health, Department of Physiology, Topeliuksenkatu 41 a A, SF-00290 Helsinki, Finland. professional group or with how the symptoms experienced are related to such problems. The aim of the present review was to clarify the stress problems among Finnish health care personnel, and therefore it is based chiefly on Finnish literature. Very few Finnish studies on stress among health care personnel have dealt comprehensively with all the potential stressors of work and man's stress reactions; thus the review is arranged according to the theoretical classifications of work characteristics $(3,12,16,25)$. The studies reviewed were selected on the basis of methodological criteria. The questionnaires and questions used in the surveys reviewed have satisfied all reasonable reliability and validity criteria. (See, eg, reference 17.) The studies reviewed also fulfilled the main formal criteria for surveys. For instance, the participation rates ranged from 72 to $96 \%$.

Some essential work characteristics have not been studied in the Finnish studies, and the gaps have been filled with the results of Swedish investigations, as work conditions are very similar throughout Scandinavia. References to the numerous studies carried out in other countries are made only when they have contributed substantially to the description of the phenomena.

This review is part of a comprehensive review on the occupational health problems of health care personnel (29) that was carried out in Finland at the initiative of the Ministry of Social Affairs and Health.

\section{Work stressors}

\section{Work content}

The content and challenge of work considerably affect the individual's well-being. Well-being and satisfaction are essentially dependent on the fit between the 
worker's characteristics and skills and the demands of his tasks. Balance between occupational demands and personal characteristics requires that the work be sometimes challenging but not cause underload or overload.

Work content is an important motivating factor in the work of health care personnel. A Swedish study (6) revealed that the most important reasons for continuing in health care professions were occupational challenge, the usefulness of the work to other persons, and the possibility to utilize one's professional education.

The overall view of the Finnish studies is very similar. Forty percent of the Finnish physicians working in municipal health care units perceived that they had the possibility to use and develop their professional qualifications at work. Of all the professional groups studied, physicians considered their work to be the most rewarding and meaningful (7).

School nurses $(98 \% ; \mathrm{N}=86$ ) felt that they were able to utilize their professional qualifications at work, and half of those questioned considered the results of their work to be discernible. Eighty-three percent of the respondents believed that they could affect the content of their work, and for $72 \%$ the work offered the opportunity for personal development. A third of the respondents also commented that their professional qualifications developed at work (2).

Ninety percent of the registered and practical nurses working with chronic patients considered their work to be meaningful. Seventy-one percent reported it was varying, and $41 \%$ felt it was relatively productive (26). Practical nurses from the Helsinki area $(\mathrm{N}=234)$ considered their work to be moderately challenging and moderately interesting (10).

But occupational challenge may sometimes cause qualitative overload. In one Swedish study (6) nearly half $(46 \%)$ of the nurse's aides thought that their medical knowledge was insufficient for their work demands. Every fourth practical nurse, every fifth registered nurse, every tenth head nurse, and every seventh physician considered themselves to be incompetent in medical questions. Incompetence concerning psychological issues was experienced even more often. In particular, the practical nurses and nurse's aides, who spend more time with patients than other professionals, felt themselves to be incompetent in psychological issues. The registered nurses and head nurses also experienced a lack of professional qualification in psychological matters, whereas the physicians considered themselves to be competent in such issues.

The occupational stressors experienced by the personnel of mental hospitals were different from the stressors experienced by other health care professionals. Whereas qualitative overload is considered problematic in most health care professions, $80 \%$ of the personnel $(\mathrm{N}=341)$ of one mental hospital reported that repetitive, routine tasks were a problem in their work (25).
The experienced variety and challenge of the work also depend on other work characteristics. Work organization, type and level of the work units, the level of the worker's self-appraisal, and the self-assessed efficiency of one's efforts affect the subjective assessments of work challenge and variety.

Challenge and variety are typical of the work of the majority of health care professionals. The situation can be assessed as positive with respect to personality development. Health care also has, however, professional groups (and personnel of particular workplaces), eg, nurse's aides and the personnel of mental hospitals, who perceive their work as monotonous and routine.

\section{Work organization}

One of the goals of work organization is to time tasks so that there is always a sufficient amount of work to do. Overlapping should also be avoided. Long waiting periods, insufficient or inadequate equipment, forgotten tasks, or errors in work performance may indicate inadequate work organization. They usually indicate weaknesses in the planning stages as well. It is possible, for instance, that all the tasks of a worker, professional group, or unit have not been considered in the planning stages or that the time needed for a task has not been assessed correctly.

Quantitative overload has been considered the physician's main problem (3). The workhours of so-called assistant physicians in Finland (the occupational title for the lowest level of graduate physicians on a hospital staff) were studied in 1980 (23); 491 assistant physicians at university central hospitals and other hospitals participated. Their workhours averaged 57.3 per week. Emergency duty considerably increased the number of workhours. There were differences between the fields of medical specialization as to the amount of active work while on emergency duty. The amount of active work while on emergency duty was the greatest among surgeons and anesthesiologists and the least among psychiatrists.

Unexpected and urgent situations and quantitative overload were experienced as the most general stressors in the work of registered nurses in surgical wards $(\mathrm{N}=121)$. Eighty-eight percent of the respondents thought that urgent situations were common in their work, and $77 \%$ believed that they had too much work to do during their normal workhours (9). The registered nurses working in the operating rooms and outpatient clinics of municipal health care units also experienced strain due to hurry and tight schedules (7). Haste and an insufficiency of personnel have also been experienced as stressors in other organizations and professions $(7,10,25,26)$.

One feature indicating problems in work organization is the fact that giving information to patients is not the responsiblity of any specific professional group or groups (8). In this respect, the situation of practical nurses and nurse's aides is especially problematic. 
These professional groups spend more time with patients than the other professionals, but they are less able to inform the patients about their illnesses or treatments (6).

The causes of quantitative overload can be summed up by the problems in two areas (16), ie, problems in planning and problems in timing tasks. Work schedules do not include enough time for the planning and preparation of tasks, office work, or cooperation between personnel. In addition, especially in large health care units, task schedules are inadequate. All "compulsory" tasks accumulate unnecessarily at certain times of the day, whereas on weekends and holidays the units try to manage with minimal staff. The unit is then understaffed if something unexpected happens. There are also problems during the vacation season, as it is difficult to acquire substitutes or the substitutes are incompetent.

Some typical characteristics of health care, eg, unexpected and urgent tasks, may also cause quantitative overload, though usually only temporarily.

\section{Responsibility}

Great responsibility is generally considered to be an essential occupational stressor. Responsibility at work may concern the immediate safety of human beings or their development, health, and economic security. Responsibility may also concern material values or the quality of work in general (5).

Another human being is always either directly or indirectly the object of the work of health care personnel. The result is exceptional responsibility.

The responsibility of health care personnel at work and their control are regulated by directives and orders (14). In addition, every citizen is legally responsible for the death, illness, or bodily harm caused by his/her negligence or carelessness. Health care personnel are not exempt from these directives and orders.

Responsibility for the compensation of injury reflects the level of responsibility of this professional group. The law on the compensation of damages usually obligates the employer to cover the damages caused by employees. But, for instance, health care professionals who run a private office are legally responsible for damages themselves (22). Examples of the legal offense of negligence include a foreign body (needle, a piece of cloth, or forceps) left inside the patient, delay in an urgent situation, insufficient examination regardless of the knowledge available, injury during thermotherapy or vaporization, and damage during an abortion (15).

Being constantly aware of great responsibility may, however, be a more general problem. Fifty percent of the registered nurses studied by Rajala (26) considered the responsibility of their work to be great or too great. Twenty-five percent of the practical nurses assessed their responsibility as being too great. Nearly all of the practical nurses in health care units in Helsinki felt the responsibility of their work to be average or greater. The practical nurses reported that their responsibility mainly concerned patients' lives and well-being, the organization and safety of the workplace, and patients' futures (10).

Incongruence between the level of responsibility and the possibility to affect decisions concerning work is one essential stressor of any job. More than half (57 \%) of the surgical ward nurses felt that the lack of clarity about their responsibilities increased mental strain (9). Comparable results were found in studies of other nurses (20) and of nurses for the mentally handicapped (16).

The responsibility of work was considered equally great in various health care professions and organizations. Responsibility, however, was not thought to be a stressor as such; unclear and undefined responsibilities were perceived as problematic.

\section{Role conflicts and role ambiguity}

Each individual worker should know his/her duties. If the worker does not or if such knowledge is poor, the situation may cause role ambiguity. If the work role is clear, the worker does not experience conflicting expectations, demands, and orders.

Nearly half $(47 \%)$ of the surgical ward nurses reported that they were unfamiliar with some of their duties. They also thought that the conflicting expectations and demands of patients and other staff members caused them strain.

Unclear work orders were also considered to increase work load. Forty-seven percent of the respondents to one questionnaire believed that the strain of work increased because physicians were not present when necessary (9).

Most of the practical nurses in health care units in Helsinki usually knew what was expected of them, but only one of five of these nurses was always aware of tasks to be done and the aims of their work (10). An even smaller proportion of respondents reported being conscious of the expectations of other people and able to anticipate the stresses of the future. Nearly all of the respondents thought, however, that it would be important to know the aims of the work. Only $25 \%$ of the respondents were never anxious because of role ambiguity.

The study on the grounds for determining the retirement age of municipal employees (7) revealed that head nurses perceived role ambiguity as a problem.

About half of the school nurses in one study believed that there was a sufficient fit between the expectations of the schools and their work. But almost a third (29 \%) felt that there was a discrepancy between the expectations of the schools and the prerequisites for their work (2).

Fulfillment of other people's expectations is a source of problems for health care personnel. Patients and their relatives, co-workers, and superiors have their 
own expectations of the work of health care personnel, and these expectations are not always congruent with each other and may not concur with the thoughts and attitudes of the person involved. The situation is very problematic when some work characteristics strongly conflict with the worker's ethical convictions. The legalization of abortions has caused problems among workers whose attitudes towards abortions are negative but who work in wards where abortions are performed. The nurses in intensive care wards often deliberate whether it is right to keep a patient alive despite considerable suffering $(8,19)$. The expectations and aggressions of a patient's relatives may appreciably increase the strain experienced by personnel in these situations.

Role conflicts and role ambiguity are relatively common at health care units. This situation is partly due to the size of the organizations and the large staffs.

Conflicting demands may often exist in work that has a challenging content. It is very important that each organization do its best to become aware of and solve its own conflicts.

\section{Social contacts and organizational climate}

Social contacts at work and the organizational climate in general are important determinants of job satisfaction. Problematic social contacts at work may considerably increase turnover, negligence of duty, and job dissatisfaction. Lack of cooperation also indicates a problematic organizational climate. Cooperation and frequent social contacts and being able to discuss work issues easily are indicators of a good organizational climate.

Several studies have revealed that professions characterized by intense social contacts are psychologically very stressful. Particularly stressful are jobs in which the objects of work are abnormal in one way or another. In organizational units or professions characterized by intense social contacts, the fluency of social contacts is even more important than otherwise, as work efficiency is highly dependent on cooperation and understanding between professional groups and individuals.

The following obstacles to cooperation have been detected in health care units $(16,25)$ : (i) unrealistic professional ideals becoming role demands; (ii) intolerance; (iii) lack of consistency between attitudes and work goals; (iv) lack of systematic plans and sustained activity; (v) lack of discussion and fear of arguments; (vi) a co-worker's opinions not being taken into account; (vii) basic care taking all the personnel's time; (viii) meetings of the entire staff made impossible by the size (small) of the staff and shift work; (ix) work overload; $(x)$ rivalry between professional groups and insufficient knowledge about the work of the other professional groups; (xi) dislike towards a patient or a co-worker; (xii) lack of motivation; (xiv) passivity, selfishness, and different concepts of work morals; (xv) a high turnover rate among personnel; (xvi) cliques.

\section{Contacts with patients}

Many health care professionals have chosen their occupation because of the wish to help other people. Other people are also a more important source of both job satisfaction and stress in health care than in some other professions.

Contacts between the staff and the clientele may be positive and rewarding in some health care sectors, eg, in maternity and child welfare clinics, or they may be neutral, as at school or in occupational health care units. But there are also some health care tasks in which anxious, fearful, or aggressive patients are encountered. Fairly often, for instance, the patients are "not themselves" and are considerably depressed and fearful at the moment of arrival at the hospital. A depressing climate may also characterize whole units or even hospitals. Even the proximity of occupational contacts may be a problem for young, inexperienced persons. A difference in cultural backgrounds between the patient and the personnel may also make it more difficult to achieve good contacts. If the patient uses concepts and ways of expressing feelings that are unfamiliar to the personnel, it is very difficult to fulfill the patient's expectations (19).

The staff may also have a very clear concept about patients' behavior. If patients behave in an unexpected way, the staff members experience difficulties in their attitudes towards them.

Work in units with very ill or dying patients has proved to be especially stressful. For instance, the nurses in terminal care units may avoid displaying compassion and emphasize the technical aspects of nursing in order to protect themselves from stress (19). Nurses working in mental hospitals, in which patients have many stressing characteristics, eg, being suspicious, hostile, unpredictable and restless, may restrict themselves to each others' companionship (25).

The study on nurses in surgical wards revealed that a patient's poor prognosis increased the mental load of the work (9). Seventy-two percent of the respondents held this opinion. Three of four respondents also felt that a dying patient in the ward increased the nurses' mental strain. The death of a patient was also considered a problem for practical nurses. Confused and highly dependent patients were, however, considered to cause even more problems (10).

Contacts with patients were assessed as neutral by several groups of health care professionals. Nurses in the surgical wards of university and central hospitals did not experience any problems in their contacts with patients (9), nor did the practical nurses in the health care units of Helsinki.

"Difficult" patients may be a real source of stress in some professions. Dentists with numerous stress reactions did not perceive the strain caused by difficult patients as a stressor (4). This perception was due to the fact that problematic patients could not stress them, that they had decided not to reveal their problems, that they had unconsciously suppressed the problems, or 
that they were unable to recognize the problems. In the researcher's opinion, the most probable explanation was the last one (4).

The characteristics of social contacts considerably affect the level of mental load in health care, as in all professions that involve intense social contacts. Taking care of anxious, dying patients is a considerable stressor according to the Finnish studies. But little knowledge is available about social contacts in health care units where the people are healthy or in a phase of life perceived as positive.

\section{Maintenance and development of professional qualifications}

The tasks of health care professionals have proved to be mentally and socially demanding. Professional qualifications and the possibility to maintain and develop them considerably affect the well-being and job satisfaction of workers in such professions. It is important that the basic qualifications for work be provided during professional training, but supplementary training, proper initiation to the work, and supervision may decrease the level of stress experienced at work.

One of five municipally employed physicians, head nurses, and nurses in mental hospitals considered their own possibilities of getting supplementary training and counseling in professional problems to be good (7). But more than half $(55 \%)$ of the nurses in surgical wards believed that their work involved insufficient professional supervision. One of four such nurses in another investigation also stated that they had had too little training for actual operations (9). Furthermore, other health care professionals have expressed problems with supplementary training and a need to develop professional skills and knowledge $(10,16,25)$.

The professional groups in health care do not have sufficient opportunities to participate in supplementary training or counseling even though both are means of supporting work ability and decreasing stress.

\section{Irregular workhours}

Work in hospitals is mainly done in shifts. The workhours are not restricted by day or week; instead restrictions apply only to the number of workhours over a two- or three-week shift (13). The length of the shifts, their division, and holidays that fall on days other than weekends are considered to be the problems of shift work. Shift work has been shown to be connected with problems in family life and in the arrangement of hobbies and social life.

Shift workers have also been shown to suffer from difficulties in falling asleep after the night shift or late evening shift. Sixty percent of the Swedish health care professionals in one study had suffered from problems in falling asleep after the night or evening shift. Only $12 \%$ of the respondents reported that they had never had problems in falling asleep in such situations (6).
The length of sleep is often shorter after the night shift than after the day shift. Forty-two percent of the practical nurses in Helsinki reported that they slept less than $6 \mathrm{~h}$ after the night shift. The quality of sleep was also considered to be abnormal. Almost all the respondents reported that they sometimes woke up while sleeping during the day (10).

Shift work increases stress. Ninety-two percent of the practical nurses of one study felt stressed after the night shift, $64 \%$ after the evening shift, and $46 \%$ after the day shift (10). Head nurses and nurses in a mental hospital said that night and evening shifts made them feel tired and insecure and that they disturbed sleep considerably more than the day shift (25).

Shift work is experienced as stressful, but it cannot be avoided in health care. For this reason, in order to decrease strain, the systems of assigning work shifts should be further developed, and other correctional measures should be sought.

\section{Violence towards workers}

Violence has increased in various social service units. The growing use of alcohol is one reason, but increases in the use of hard drugs have also caused violence. The personnel of outpatient clinics, emergency units, and psychiatric health care units have often been the objects of violence. A Swedish study on the accidents of municipal clerks ( $\mathrm{N}=3849)$ revealed that $11 \%$ were due to a patient's violent behavior. The object of violent behavior was often a nurse $(41 \%)$ in a mental hospital or a nurse's aide $(34 \%)$. Registered nurses $(6 \%)$, pediatric nurses, cleaners $(2 \%)$, and social workers (2\%) had also been attacked (28).

A violent act takes place every 14th day at the outpatient clinic for acute psychiatric patients of the Karolinska Institute in Sweden. Forty-three staff members were attacked in 63 violent actions (6 female doctors, 10 male doctors, 16 nurses or psychiatric nurses, and 11 other nurses). The majority of violent acts $(\mathrm{N}=$ 29) were committed by drug abusers suffering from an overdose, whereas eight were committed by psychiatric patients (21). The staff of a Finnish mental hospital experienced the violence of patients, and especially the threat of violence, as a general stressor (25). Violence has also been considered to be a stressor in outpatient clinics and health care units.

\section{Stress reactions}

Stress elicits several changes in man's psychological and physiological functions and manifests itself also as subjective symptoms. Subjective stress symptoms are usually classified as psychological and psychosomatic symptoms. Anxiety, nervousness, tension, depression, and irritation are stress-related psychological symptoms. Stomach pain, chest pain, irregular heart beat, headache, nausea, and fatigue are considered to be typical psychosomatic symptoms. These symptoms have 
also been measured frequently in the stress studies of health care personnel. Some surveys have studied other symptoms as well, eg, memory disturbances, difficulties in concentrating and sleeping, and negative attitudes towards work. Recently the phenomenon of burnout has been the topic of several reviews in the sector of health care. The concept of burnout refers to the loss of psychological, social, and physiological resources and occupational motivation.

Stress studies done in Finland on various professional groups have revealed that $10-20 \%$ of the working population reports a considerable number of stress symptoms. Psychosomatic symptoms are experienced more frequently than psychological ones (11). In the study on the grounds for determining the retirement age for municipal occupations (7), the subjective symptoms were surveyed through the use of a questionnaire. Ten percent of the women aged 45 to 57 years $(\mathrm{N}=$ 261) reported that they often had subjective symptoms, with the exception of the registered nurses in operating rooms and outpatient clinics (table 1). Nurses in mental hospitals, practical nurses, nurse's aides, and bathing attendants reported more symptoms than registered nurses. The registered nurses in operating rooms and outpatient clinics experienced fewer symptoms than other nurses, and the symptoms they did experience occurred less often than among other nurses. Head nurses in health care units and hospitals also reported fewer symptoms than other nurses.

The physicians reported more psychological symptoms and less psychosomatic symptoms than the nurses (table 1). Male physicians had more psychosomatic symptoms than female physicians. The two groups reported an equal number of psychological symptoms. Female dentists experienced considerably more psychological symptoms than male dentists. The profes- sion of nurse in a mental hospital was the third group that comprised both men and women. Male nurses in mental hospitals experienced fewer psychological and psychosomatic symptoms than female nurses in such hospitals (7).

Subjective stress symptoms experienced by the nurses and head nurses of surgical units were studied by Joenpelto \& Vanhanen (9). Twenty percent of the respondents experienced stress nearly always or very often. Overall fatigue was experienced often by $16 \%$ of the respondents. The nurses also reported their intentions to avoid difficult situations, feelings of inferiority, lack of initiative, and moodiness. The subjects did not, however, feel irritated or uncontrolled, nor was the feeling of deep depression expressed. This result of this study is comparable with the findings of Ilmarinen et al (7). The symptoms studied by Joenpelto \& Vanhanen (9) describe the experienced level of mental resources and avoidance reactions, which occurred equally as often in the study done at the Institute of Occupational Health in Helsinki (7). (See, eg, table 1).

When the stressors and stress reactions of the health care personnel of one unit were compared according to status, the comparison revealed that head nurses had more stress reactions than assistant head nurses, specialized nurses, or registered nurses (9). Mattila (20) has also shown that head nurses' work involves more stress than that of other nurses.

The results of the studies by Joenpelto \& Vanhanen (9) and Mattila (20) conflict with the results of Ilmarinen et al (7). The lack of agreement may, however, be due to the fact that, in the study of Ilmarinen et al, the age of the various groups of subjects was similar, whereas in the other studies the average age of the head nurses was higher than that of the other profes-

Table 1. Distribution of reported mental resources, psychological symptoms, and psychosomatic symptoms among 45- to 57-year-old municipal employees in various professions (7).

\begin{tabular}{|c|c|c|c|c|c|c|c|}
\hline & $N$ & $\begin{array}{c}\text { Good } \\
\text { mental } \\
\text { resources } \\
(\%)\end{array}$ & $\begin{array}{c}\text { Sleep dis- } \\
\text { turbances } \\
(\%)\end{array}$ & $\begin{array}{c}\text { Psychologi- } \\
\text { cal } \\
\text { symptoms } \\
(\%)\end{array}$ & $\begin{array}{c}\text { Psychoso- } \\
\text { matic } \\
\text { symptoms } \\
(\%)\end{array}$ & $\begin{array}{c}\text { Memory } \\
\text { distur- } \\
\text { bances } \\
(\%)\end{array}$ & $\begin{array}{c}\text { Avoidance } \\
\text { reactions } \\
(\%)\end{array}$ \\
\hline \multicolumn{8}{|l|}{ Women } \\
\hline \multicolumn{8}{|l|}{ Nurse in a mental } \\
\hline hospital & 97 & 10.6 & 22.1 & 17.9 & 22.2 & 8.4 & 22.7 \\
\hline Nurse's aide & 240 & 16.4 & 25.0 & 16.3 & 24.8 & 17.6 & 21.6 \\
\hline Practical nurse & 280 & 20.3 & 20.2 & 13.4 & 16.4 & 13.4 & 17.1 \\
\hline Bathing attendant & 155 & 20.6 & 17.2 & 9.2 & 25.5 & 17.3 & 15.8 \\
\hline Dentist & 81 & 22.5 & 15.0 & 17.3 & 7.5 & 9.9 & 23.5 \\
\hline nurse & 261 & 22.8 & 10.9 & 10.4 & 10.1 & 11.5 & 20.9 \\
\hline Head nurse & 171 & 28.4 & 11.3 & 9.9 & 6.5 & 11.2 & 17.1 \\
\hline Chief head nurse & 102 & 29.7 & 7.9 & 9.8 & 6.9 & 11.9 & 17.7 \\
\hline \multicolumn{8}{|l|}{ Registered nurse } \\
\hline \multicolumn{8}{|l|}{ in an operating } \\
\hline \multicolumn{8}{|l|}{ room or outpatient } \\
\hline clinic & 85 & 34.9 & 9.4 & 8.2 & 6.0 & 8.3 & 16.5 \\
\hline Physician & 26 & 42.3 & 7.7 & 11.5 & 7.7 & 7.7 & 11.5 \\
\hline \multicolumn{8}{|l|}{ Men } \\
\hline \multicolumn{8}{|l|}{ Nurse in a mental } \\
\hline hospital & 70 & 22.1 & 14.7 & 12.9 & 14.9 & 12.9 & 23.5 \\
\hline Dentist & 14 & 28.6 & 21.4 & 7.1 & 7.7 & 14.3 & 14.3 \\
\hline Physician & 61 & 39.7 & 1.6 & 11.9 & 3.3 & 6.6 & 14.8 \\
\hline
\end{tabular}


sional groups. Age has been thought to increase the symptoms experienced. The study by Ilmarinen et al (7), however, covered several organizations, whereas the other studies concerned only a few health care units. It has been frequently stated that both stressors and stress reactions vary according to the organization being studied.

\section{Evaluation of stress studies on health care}

The studies on stress in health care have dealt with the potential stressors at work and the stress reactions experienced by health care personnel. The theoretical frames of reference have ranged from relatively narrow concepts of job satisfaction or stress orientation $(2,9)$ to a more comprehensive stress orientation $(10$, $16,25)$. Studies based on narrow concepts of job satisfaction or stress have dealt with only some of the potential stressors and stress reactions, though in some studies the environmental and individual factors potentially associated with stress have been comprehensively included in the theoretical approaches of the studies $(6,10,25)$.

Most studies have used questionnaires as the method of studying work characteristics and stress reactions. Differences in theoretical approaches have caused variability in the methods used. Only studies with a comprehensive theoretical approach $(10,16,25)$ have managed to measure several generally known potential stressors and stress reactions. The main stressors and stress reactions have also been measured in the studies that have not included individual characteristics (eg, the coping mechanism) in their theoretical approach $(7,16)$. Some studies have used interviews (6), group work (16), and work analysis based on observations (7) in addition to questionnaires.

The studies on stress among health care personnel are cross-sectional, and therefore changes in the work characteristics, stress reactions, and the relationships between them over time have not been investigated. Only the study by Ilmarinen et al (7) has included a follow-up study, but the results have not been published yet.

The majority of studies reviewed considered stress in one or a few organizations or professions; only the study on the grounds for determining retirement age for municipal employees comprehensively surveyed stress among various professional groups of health care personnel in various organizations. However, the studies on stress in one or a few organizations or professional groups were based on a representative sample of the population or dealt with the whole target population $(2,6,9,10,16,20,23,25,26)$. Thus the results of these studies, too, can be considered reliable. The high participation rates in the studies $(72-96 \%)$ also increase the reliability of the data reviewed. It should be remembered, however, that the results of the studies describe the stress and stress reactions experienced mainly in hospitals, because few studies have dealt with professionals working in health care centers $(7,10)$.

Due to inconsistencies in the theoretical approaches, methods, and organizations or professional groups of the reviewed studies, their results are not comparable as to statistical meaning. The results have, however, revealed considerable consistency in the assessments of some work characteristics. Several studies found that quantitative overload, role ambiguity and conflicts, social contacts at work, insecurity, workhours, and a lack of adequate means to increase professional qualifications are problems common to various professional groups in different organizations. But the studies also showed that the content and challenge of the work and the responsibility experienced at work vary according to profession and organization; these results are still relatively general and cannot lead, eg, to solutions of problems.

The questionnaires used in stress studies contain items on work characteristics that are highly abstract. In order to make the assessments of work characteristics more precise, the causes for the assessments should also be studied through such questions as why, how, when, or in what kinds of situations. Answers to these questions, however, depend on each respondent's level of consciousness, motivation, and verbal fluency. Interviews and directed problem-solving groups would probably give more precise answers to such issues. Also methods for studying and improving the coping mechanisms of health care personnel need to be developed, as health care work will always entail factors causing stress (eg, severely ill or dying patients, shift work).

The goals for the psychological aspects of labor protection affect the direction of studies. It is not a sufficient goal for labor protection to know the general stressors or the percentage of workers suffering from psychological or somatic stress reactions. The goals of labor protection also include increased well-being through corrective and preventive actions at work. In some studies the proposals for corrective actions have been collected through a questionnaire technique (16, 25) and a group work method (16). These methods should be applied more frequently in studies on stress in health care, and the methodology should be developed further. There are ideas for preventive actions, but they have remained only ideas. The effects of work reorganization, the clarification of responsibilities, increased supplementary training and professional supervision, and the application of directions for the prevention of violence (1) on the stress and strain of health care professionals should be studied as a means to diminish stress and increase well-being and productivity.

\section{References}

1. Våldsrisker i arbetsmiljön [Risks of violence in the work environment]. Arbetarsskyddsstyrelsens författningssam- 
ling. Stockholm 1983. (AFS) 1/1983.

2. Aronen A. Helsingin kaupungin terveysviraston kouluterveydenhoitajien työssäviihtyvyys [Job satisfaction of school nurses in the city of Helsinki]. Helsinki School of Nursing, Helsinki 1980.

3. Caplan RD, Cobb S, French JRP, Van Harrison R, Pinneau SR. Job demands and worker health: Main effects and occupational differences. US Department of Health, Education and Welfare, Washington DC 1975. (HEW publication no 75-160 (NIOSH)).

4. Cooper CL. Dentists under pressure: A social psychological study. In: Cooper CL, Marshall J, ed. White collar and professional stress. John Wiley \& Sons, Chichester 1980, pp 3-17.

5. Elo A-L. Assessment of psychic stress factors at work. Institute of Occupational Health, Helsinki 1986. (Occupational health care 7).

6. Gardell B, Gustafsson RÄ, Brandt C, Tillström I, Torbiörn I. Sjukvård på löpande band [Health care on a conveyor belt]. Bokförlaget Prisma, Stockholm 1979.

7. Ilmarinen $\mathbf{J}$, Wägar $\mathrm{G}$, Suurnäkki T, Tuomi K, Kohvakka A, Eskelinen L, Merisalo T, Hurri $H$, Järvinen $\mathrm{E}$, Huuhtanen $\mathrm{P}$, Hernberg S. Kunnallisten viranhaltijain ja työntekijäin eläkeikien perusteiden tutkimus [Investigation of the bases for the retirement age of municipal employees]. Institute of Occupational Health, Helsinki 1983. (Preliminary report).

8. Jacobson SP. Stressful situations for neonatal intensive care nurses. Am J Matern Child Nurs 3 (1978) 144 - 150.

9. Joenpelto L, Vanhanen K. Sairaanhoitajan työpaine ja potilaan hoito [Work stress of nurses and patient care]. Helsinki School of Nursing, Helsinki 1981

10. Jokinen M, Pöyhönen T. Apuhoitajan työn stressi ja muut työsuojeluongelmat. [Stress and other occupational health problems afflicting practical nurses]. Institute of Occupational Health, Helsinki 1980. (Tutkimuksia 166).

11. Kalimo R. Psyykkiset ja epämääräiset somaattiset oireet työterveysongelmina [Psychological and unspecfic somatic syndromes as indicators of work-related health impairment]. Työterveyslaitoksen tutkimuksia 3 (1985): $4,367-384$.

12. Kalimo R, Kauppinen-Toropainen $\mathbf{K}$, Lindström $\mathrm{K}$. Psyykkinen työsuojelu, haittatekijä- ja toimialakohtainen katsaus [Psychological and social factors in working life]. Institute of Occupational Health, Helsinki 1979. (Katsauksia 30).

13. Kauppinen-Toropainen K, Vartia-Huomanen M, Heiskanen J, Hyyppä M, Hänninen V, Ilmarinen J. Vuorotyö ja epämukava työaika [Shift work and inconvenient workhours]. Institute of Occupational Health, Helsinki 1981. (Katsauksia 47).

14. Kokkonen P. Terveydenhoitohenkilöstön oikeudellinen asema ja vastuu sekä terveydenhoitohenkilöstöön kohdistuva valvonta [The legal status and responsibility of health care personnel and the supervision of this group of professionals]. In: Suomen Lakimiesliiton kustannus Oy. Vastuu ja oikeusturva terveydenhuollossa. [Responsibility and legal protection in occupational health care]. Helsinki 1983, pp 2-33.
15. Kokkonen P. Terveydenhuoltohenkilöstön oikeudellinen asema [Legal status of health care personnel]. Lääkintöhallitus tiedottaa 2 (1983): 18, 8-9.

16. Leppänen A. Psyykkinen kuormitus lähikasvattajien ja kehitysvammaisten hoitohenkilökunnan työssä [Stressors and stress reactions of professional personnel at institutions for child care and institutions for the mentally handicapped]. Institute of Occupational Health, Helsinki 1983. (Liiteraportti 2).

17. Leppänen A. Työn piirteiden mittaaminen kyselymenetelmällä [Measurement of work characteristics by questionnaire methods]. Työterveyslaitoksen tutkimuksia 2 (1984): 1, 5- 16 .

18. Levi L. Psychological stress and disease, a conceptual model. In: Gunderson EK, Rahe RH, ed. Life stress and illness. Charles C Thomas, Springfield, IL. 1974, pp 8-33.

19. Marshall J. Stress amongst nurses. In: Cooper CL, Marshall J, ed. White collar and professional stress. John Wiley \& Sons, Chichester 1980, pp 19-61.

20. Mattila U. Sairaanhoitajan työtyytyväisyys ja työssä koettu stressi [Job satisfaction and work stress experienced by nurses]. University of Helsinki, Helsinki 1976. (Master's thesis).

21. Mindus $\mathbf{P}$, Struwe G. Våldshandlingar på en psykiatrisk akutmottagning. En retrospektiv studie [Handling of violence in acute psychiatric health care: A retrospective study]. Läkartidningen 74 (1977) 4606-4607.

22. Modeen T. Sairaanhoidossa tapahtuvien vahinkojen korvaaminen [Compensation for accidents occurring during medical care]. Suom lääkäril 34 (1979) 1155-1158.

23. Olkinuora $\mathrm{J}$, Koskiniemi $\mathrm{H}$. Apulaislääkärin työhönsidonnaisuus ja koulutus (Assistant physicians' work restriction and trainingl. Suom lääkäril 36 (1981): 20, $1573-1582$.

24. Pines AM, Aronson E, Kafry DB. From tedium to personal growth. The Free Press, New York, NY 1981.

25. Pöyhönen $T$. Psykiatrisen sairaalan työolojen ja työntekijäin piirteiden sekä niiden vuorovaikutuksen yhteydet työntekijän psyykkiseen terveyteen: kuvaileva osa [Characteristics of the work conditions and personnel in a psychiatric hospital and their relationship with the workers' mental health: A description]. Institute of Occupational Health, Helsinki 1981

26. Rajala S. Hoitohenkilökunnan kokemuksista työstään pitkäaikaissairaiden parissa [Experiences of health care personnel with patients with chronic illnesses.]. Helsinki School of Nursing, Helsinki 1981.

27. Selye H. The stress of life. McGraw-Hill Book, New York, NY 1956.

28. Stymne I. Vảldsrisker i arbetsmiljön [Risks of violence in the work environment]. Arbetarskyddsstyrelsen, Solna 1981.

29. Tuppurainen M, ed. Terveydenhuoltoalan työsuojeluongelmat [Problems of labor protection in health care] Työterveyslaitoksen tutkimuksia 2 (1984): suppl.

Received for publication: 20 September 1986 